\title{
Imagining U.S. Labor Relations without Union Security
}

\section{By: Ann C. Hodges, Professor of Law, University of Richmond}

\begin{abstract}
Attacks on union finances are intensifying. These assaults, which come in various forms, have the potential to jeopardize the current systems of labor relations in the United States in both private and public sectors. This essay analyzes what might happen if the challenges are successful. Unions may shrink further in size or power, or alternatively, respond to new conditions in ways that strengthen them. Removal of union security might prompt legal change such as elimination of the duty of fair representation, elimination of the system of exclusive representation, or permitting the union to charge nonmembers for actual representation. These changes, if they occur, will be disruptive although they might result in a system more suited to today's workplace. Regardless of the immediate outcome, it seems certain that labor-management conflict will not be eliminated, though it may be diverted for a time or changed in form.
\end{abstract}

Key words: union dues, union security, membership, exclusive representation system, duty of fair representation

For many years union finances have been under attack by organizations dedicated to eliminating the ability of unions to charge workers for representation unless the workers voluntarily choose to pay. Whatever the motivations of these groups, the attacks, which are gaining traction, have the potential to undermine the existing system of labor relations in the United States. This essay is a thought experiment that will examine what might result in the event that these efforts are successful. What might the labor relations system in the United States look like with a system of voluntary dues? Of necessity, there is much that is speculative about this effort. Nevertheless, in light of the potential impact, this is speculation worth doing.

The essay begins with a brief analysis of the union security system and its centrality to the current labor relations system in the United States. Following the analysis of the system is an abbreviated discussion of current efforts to eliminate 
the ability of unions to charge unwilling employees the costs of their representation. This analysis is followed by a series of hypotheses about the change that would result if unions could not charge objecting employees for representation. These hypotheses focus particularly on the impact on the actors in the labor relations system and on the structure of the system itself. Of course the two are interrelated. The actors both influence and are influenced by the structure of the system so any changes will be the result of the interaction of the two.

\section{Union Security in the United States}

The union security system, typically known as fair share in the public sector and financial core membership in the private sector, allows unions to charge the cost of representation to workers that the exclusive representation system requires them to represent, even if those employees do not join the union. Union security is a corollary to the exclusive representation system. It evolved in conjunction with the National Labor Relations Act (NLRA) in the private sector and was imported into the public sector by state statutes patterned after the NLRA. Initially, the NLRA did not prohibit unions and employers from negotiating agreements that required employees to be union members as a condition of employment (Dau-Schmidt 2014, p.1039). Over time, with both statutory amendment and judicial interpretation, the law evolved. Currently, under the NLRA, employees can be required to pay only the cost of collective bargaining and contract administration, including processing of grievances, as a condition of employment (CWA 1988, pp. 762-63). They cannot be required to join the union or to pay for other activities of the union, including 
political activities. The dues those who choose to become full members of the union, however, can be used for these purposes. Further, since 1947 the NLRA has allowed states to pass laws that bar union security agreements (NLRA, Section 14(b)). These laws are commonly called "right-to-work" laws. As states began to pass laws allowing public employees to organize and bargain collectively, many state laws also allowed negotiation of union security agreements or in some cases, mandated fair share payments by law (Malin 2011, p. 752). The same limitations that apply in the private sector apply to the use of fair share fees. They can only be used for representational activities, not political activities (Abood 1977, pp. 235-36).

Contractual provisions allowing the employer to deduct dues or fees from the employees' pay and remit them to the union, with employee authorization, are common in the private sector. As a practical matter most employees authorize such deductions as an easy method of paying dues and fees. In the public sector, some states allow payroll deduction without employee authorization to minimize the risk of discharge for nonpayment (Malin 2011, p. 752).

Union security agreements allow unions to charge for services that they are required to provide. In the United States, both the NLRA and most state collective bargaining laws use the exclusive representation system, a system not adopted by most other developed countries (Malin 2011, pp. 391-92; Dau-Schmidt 2014, p. 396). Under the exclusive representation system, once a union is chosen by a majority, it represents all of the employees in the designated bargaining unit, even those who do not desire representation (Malin 2011, pp. 391-92). The employer 
must bargain with the selected union and the resulting collective bargaining agreement covers all.

This system was adopted because it provides a level of stability in bargaining relationships and minimizes the disruption that would occur if multiple unions represented employees working in the same jobs (Bok 1971, p. 1426). The employer has to negotiate with only one union and administer only one contract for each unit. The union is prohibited from negotiating different benefits for its members and is required to represent all in the bargaining unit fairly and in good faith (Dau-Schmidt 2014, pp. 1055-56). In particular the union must represent all employees in the grievance and arbitration procedure, which is the vehicle for enforcing almost all collective bargaining agreements (Malin 2011, p. 676) and required to be included in contracts by law in some public sector statutes (115 ILCS 5/10(c); 5 ILCS 315/8). If the union does not represent all employees fairly, it may be sued for breach of the duty of fair representation, which can subject the union to substantial damages in addition to the costs of litigation (Dau-Schmidt 2014, pp. 904-16). The reality is that many unions provide the best representation to nonmembers for fear of being charged with breach of the duty.

Accordingly, the union security agreement is an integral part of the labor relations system that has developed in the United States. Without it unions are mandated to provide free services, creating a classic collective action problem (Olson, 1971 pp. 15, 68). There is little incentive for individual employees pay for services that benefit all (Olson, 1971 pp.15-16). Even dedicated union members may cease payment when they see others receiving the same benefits and services 
without cost. Indeed any economically rational actor will be tempted to do so (Olson 1971, p. 76, 88). As Mancur Olson explains, some sort of compulsion or incentive is essential to the success of large labor unions and the most common is union security (Olson 1971 pp. 68-76). Thus, ultimately, every reduction in the ability of unions to charge the costs of representation puts the entire system at greater risk of collapse.

While employees who pay fair share payments may be compelled to pay for representation that they do not desire and for benefits that they would not choose, there is a communitarian purpose for the requirement. Like taxes paid to the government, fair share fees require all to pay for what all may benefit all. These common goods could not be provided based on voluntary payment because it is rational for each individual to avoid payment (Olson 1971, pp. 88-89). Why should any individual pay for a road on which he or she may or may not drive or for a fire department that he or she may never use? Others will pay and he or she has the benefit of availability without payment. But of course, every taxpayer has the same incentive. Thus, public goods can only be reliably financed through a system requiring compulsory payments.

\section{Attacks on Union Security}

The current attacks on union security agreements come in three forms. First, there is an effort to expand the number of states adopting right-to-work laws. And indeed, Wisconsin Governor Scott Walker, a former Republican candidate for president, proposed a national right to work law as part of his campaign platform (Bauer 2015). Indiana, Michigan and Wisconsin have adopted right-to-work laws in 
the last three years (Heynen 2015). These Midwestern states have traditionally had a strong union presence with corresponding political power. That right-to work succeeded in these states is evidence of the growing strength of the movement. Second, there are legal challenges to the union security regime. In two recent Supreme Court cases, Knox v. SEIU, Local 1000 (2012) and Harris v. Quinn (2014), Justice Samuel Alito's majority opinions questioned the constitutionality of union security, inviting a challenge that came to the Court in 2015 in Friedrichs $v$. California Teachers Association (Friedrichs 2015). Friedrichs attacked California's public sector statute allowing fair share agreements for education employees, arguing that it violated the First Amendment rights of objecting employees (Friedrichs 2015). On March 29, 2015, an equally divided Court affirmed the lower court's holding that the California statute is constitutional. (Friedrichs 2016). Prior to the death of Justice Scalia, however, it appeared likely that the Court would find the statute unconstitutional. The decision will not end the litigation on this issue. Another case will almost certainly return to the Court and the outcome will depend on Justice Scalia's replacement. The third form of attack is the enactment of laws that limit payroll deduction of union dues and fair share fees. In recent years several states have passed laws limiting payroll deduction for particular categories of employees or for particular types of expenditures, generally political expenditures (Hodges 2012, pp. 601-04). In the absence of payroll deduction, it is more difficult and cumbersome for unions to collect dues and fees and their resources drop as a result (Hodges 2012, pp. 605-07). 
The increasing strength of these efforts to limit union resources compels consideration of what the result of substantial success might look like. The consequence, and for some the goal, of these efforts is to reduce the power of unions, at least in the short term. How might unions respond and how might labor and employment relations and law change as a result?

\section{Changing Landscapes}

States that currently have right-to-work laws provide a model for assessing how a widespread voluntary membership regime might work for unions. As a general rule, although not exclusively, membership and unionization is lower in those states (Bureau of Labor Statistics 2015). The reduced resources make representation more challenging and limit union power, resulting in fewer employee protective laws in right-to-work states (Hodges 2009, pp. 755-65). Yet unions are not non-existent, and in some cases have not only survived but thrived (Oswalt, 2007, p. 704). The same is true for public sector unions in states that outlaw public sector bargaining (Hodges \& Warwick 2012, pp. 278-87). An optimistic view for unions suggests that they might benefit from expanding right-towork laws because they would, of necessity, have to engage in more effective internal relationship building and resultant activism in order to increase and maintain membership (Oswalt 2007, pp. 712-16; Hodges 2009, p. 770). Building the union using a model based on relationship development is time-consuming and labor intensive, but may lead to greater commitment and activism among the membership (Hurd 1989, p. 6). The "business unionism" that has been the prevalent model in the United States may give way to social movement unionism 
(Oswalt 2007, pp. 706-11). Signs of a resurgence of social movement unionism already exist and many unionists and labor scholars advocate greater use of the model for more powerful and effective unions (Getman, 2010; Schiavone, 2008).

It is unclear, however, whether this labor-intensive model of unionization will maintain its effectiveness in the long run. First, active involvement in political and civic organizations in American society has fallen generally (Putnam 2000, p. 46), so maintaining grassroots participation over the long term may be challenging. Second, American labor unions began as grassroots organizations but evolved into the institutional bureaucracies they are today for several reasons (Olson 1971, pp. 73-76). One is the natural life cycle of organizations, suggesting that today's grassroots organizations may either evolve to larger, more complex institutions or die. The other is the need for the resources of large institutions to combat the substantial power of employers (Fisk \& Chemerinsky 2013, p. 1031). To deal with employers, unions need lawyers, accountants, actuaries, economists, expert negotiators, and research staff (Abood 1977, pp. 221-22). Extensive use of experts, while not inherently inconsistent with grassroots activism, can cause tensions and in some cases, distance or disaffection of members (Hodges 2011, pp. 903-05). It is a challenge, though not an insurmountable one, to maintain grassroots participation along with institutional power (Narro 2008, pp. 240-44).

A related optimistic note for labor advocates is the growth of worker centers and alternative forms of employee organizing (Oswalt 2016, pp. 21-42) such as Making Change at WalMart (Making Change at Walmart 2015) and the National Day Laborers Organizing Network (Dziembowska 2010, pp.141-53). These grass roots 
organizations engage in worker advocacy, yet are not unions (Fine 2006, pp. 2-3, 1415; Milkman 2010, pp. 11-15). They come in many forms - some are industry-based, some are employer-based, and some focus on workers from particular racial and ethnic groups (Milkman 2010; Fine 2006). These groups have attracted workers who have not participated in traditional unions for a variety of reasons (Milkman 2010, p. 14-18). While some campaigns that begin as nontraditional organizing move to traditional unionization or intend to do so, others remain worker advocacy groups without official union status (Milkman 2010, pp. 14-18; Fine 2006, pp. 12056; Garea \& Stern 2010, p. 125). The groups have had some major successes. Some large employers targeted have raised wages, worker protective legislation has been enacted, and illegal labor practices have ended with wage recovery for workers (Milkman 2010, p. 15; Oswalt 2016, pp. 30, 39-40). Yet these groups struggle for funding without a steady source of union dues and fees for support (Rosenfeld, 2006, p. 479). And many are financially supported by unions, so a reduction of union resources will affect the organizational health of these groups as well.

It is uncertain how this model of labor advocacy will work over the longterm, particularly if unions decline further and are unable to provide substantial funding support. Professor Benjamin Sachs has suggested a regime of what he calls "unbundled labor law" which would essentially formalize organizations engaged in political advocacy into workplace-based political unions, voluntary associations of workers unable to compel agency fees or to engage in collective bargaining (Sachs 2013, pp. 182-98). This model would legally authorize these nontraditional labor groups as workplace representatives. Professor Sachs argues that unions without 
bargaining rights will generate less employer opposition (Sachs 2013, pp. 185-95).

It is not clear whether such organizations would have effective power, either in the workplace or the political arena, however, nor is it apparent that they could sustain themselves without the support of traditional unions that have a steady funding source (Devinatz 2015, pp. 105-09). Professor Oswalt also views this model as potentially successful although he argues that the results are unpredictable because the model is improvisational. (Oswalt 2016, pp. 85-87)

A less optimistic vision of the end of union security would be a substantial reduction in the already lower union membership and representation, making unions weaker and reducing their ability to both represent workers in the collective bargaining process and participate in the political arena. Weakness in the collective bargaining arena will lead to a reduction in the differential wages and benefits between unionized employment and nonunion employment (Mishel 2012), discouraging unionization further. Additionally the decline in the organized percentage of the workforce has coincided with and contributed to an increase income inequality (Mishel 2012). The increase in productivity of American workers has increasingly been distributed to shareholders rather than workers since the 1970s (Lazonick 2015, p. 156). Absent a resurgence of unions, the gap between productivity and pay is likely to continue, leading to ongoing inequality and precarious employment. The decline of unionization may lead to increased governmental costs as well since unionized employees are far more likely to have employer-provided health insurance and pensions (Mishel 2012). Without employer-provided benefits more individuals will rely on government-subsidized 
health insurance and social security benefits, and perhaps other government programs and subsidies as well.

In the political arena, as the most powerful voice for workers' rights, albeit in a weakened state, unions have supported legislation at the federal and state levels to protect workers' rights. Additionally, they have supported political candidates that advocate for workers' rights. A diminished labor movement will provide more space for already powerful corporations and wealthy individuals to dominate political discourse and secure favorable legislation. A robust democracy needs a variety of voices to function effectively and the reduction or loss of the workers' voice will adversely affect the democratic functioning of the political process.

It is unlikely, however, that employer dominance will quell all dissent for long. Eventually exploited employees will rise up in opposition in some way (Duff 2011, p. 143). Conflict in the workplace is inevitable, as employers want to pay as little as possible for necessary labor and workers want as much as possible for their work in order to support themselves and their families (Vegelahn 1896, p. 1081). During the Great Depression, the suffering of workers ultimately led to militancy, and labor organizing and bitter strikes surged despite the lack of any real legal protection for workers (Bernstein 1970, pp. 37, 92, 126-27, 217-317). While some factors suggest that the collective mentality is weakening, in low wage workplaces collective action is growing. Unions are already employing creative new strategies designed to respond to new realities in the workplace. Thus, labor might not be down for long. 
In addition to the direct impact on unions, employees and employers, there may well be an impact on the law and the labor relations system it creates. As discussed above, union security is one aspect of the comprehensive labor relations system that was established in the private sector 80 years ago and moved to the public sector thereafter. While some current attacks are limited to the public sector, others, such as right-to-work laws, affect both. Removing one element of the system alters the entire system. Removing the ability of unions to charge for representation may lead to legal challenges to the duty of fair representation. Can the law justify requiring unions to represent workers without compensation, particularly when the resources come from those who willingly pay? The law is then forcing some workers to subsidize representation of other workers who are not unable to pay, just unwilling. Indeed, unions must make every effort to provide excellent representation to nonmembers because failing to do so subjects them to greatest risk of a costly lawsuit for breach of the duty of fair representation since these workers may already be hostile to the union or anticipating reduced service. While it is difficult to prove a breach because the standards are relatively deferential to the union's decisions about what to emphasize in negotiations and how to process grievances (Dau-Schmidt 2014, pp. 904-15), the most significant risk is when the plaintiff is a nonmember because the motivation of the union is easier to establish.

Increasing legal challenges to the duty of fair representation may arise with the spread of right-to-work. Requiring unions and their members to pay for representation of workers who choose not to pay restricts their ability to engage in 
their own free speech by reducing the resources available to them (Fisk \& Poueymirou 2015, pp. 88-91). Accordingly, unions may file lawsuits challenging right-to-work laws, the duty of fair representation and/or the entire exclusive representation system in both the public and private sectors on this basis. So long unions, particularly those in highly unionized states, could negotiate union security agreements, there was less incentive to litigate this issue but if union security is substantially reduced or eliminated, unions may challenge the constitutionality of the system.

Another union strategy may involve pushing for legislative changes at the federal, state and local levels to make it easier to obtain and maintain membership. For example, unions in California have sought, and in some cases, obtained legislation requiring employers to provide unions the opportunity to make a half hour orientation presentation to newly hired workers to convince them to join the union (Cadelago 2015). While passage of such legislation at the federal level and in states where unions have less powerful lobbies is unlikely, in some states legislative changes enabling easier organizing of public workers are a real possibility.

Additionally, unions may begin to charge nonmembers for representation in the grievance procedure. A recent case before the NLRB questioned the legality of such charges, but it settled before the Board decision (United Steel and Service Workers, pp. 3-4). The administrative law judge, in accord with earlier cases, found a violation of the NLRA because the fee for grievance processing coerced employees in their right to refrain from union membership (United Steel and Service Workers 2014, pp. 6-7). After exceptions to the decision were filed, the Board solicited 
amicus briefs on the issue, asking whether it should reconsider the existing law and if so, what factors it should consider in deciding whether the amount of the fee might be coercive (Notice and Invitation 2015, pp. 1-2). Further, the request asked how the union might be able to collect the fee without violating the law (Notice and Invitation 2015, pp. 1-2). The fee at issue was the same as the amount of chargeable fair share fees in states that allow union security agreements (United Steel and Service Workers 2014, pp. 3-4). The fee applied for the duration of the collective bargaining agreement and if the grievance was still in process at contract expiration, for the duration of the grievance (United Steel and Service Workers 2014 pp. 4). In the public sector, the Nevada Supreme Court found such a fee did not impermissibly coerce or discriminate against nonmembers of the union. (Cone 2000). If union security agreements are nullified nationally or in more states, unions may increasingly charge such fees, and the NLRB and public sector equivalents may be more likely to find them lawful (Fisk \& Sachs 2013, pp. 874-79).

Alternatively, these agencies may decide that unions can charge for representation only if employees have the option to pursue their claims without representation, thus limiting the coercive impact of the charge. In United Steel and Service Workers, employees could file their own grievances but could not pursue them past the third step (United Steel and Service Workers 2014, p. 3). Most importantly, employees did not have access to arbitration unless the union agreed (United Steel and Service Workers 2014, p. 3). If employees can access the grievance and arbitration procedure without agreement of the union, however, the nature of that procedure will change. Employers will lose the benefit of the union's 
screening function and may be required to arbitrate more cases, making the grievance and arbitration procedure more costly for the employer. This in turn may make employers more reluctant to agree to arbitration. Or employers may exact more in negotiations from unions that desire to preserve arbitration. One possible concession might be an agreement to include legal claims in the grievance and arbitration procedure, a concession the Supreme Court has held that unions can make (14 Penn Plaza 2009, pp. 265-66, 274).

While I have argued elsewhere that an agreement to arbitrate legal claims is not in the union's best interests, if the duty of fair representation does not require employees to represent employees in the process, the risk for the union is significantly reduced (Hodges 2010, pp. 34-35). The downside for employees, however, is that they lose some legal rights in the process including the jury trial and depending on the structure of the procedure, among other things, the statute of limitations may be shorter, and discovery and available remedies may be limited (Sternlight 2015, pp.1314-15, 1339). Further employees may be unable to obtain legal representation to substitute for the union representation that would be available to members (Sternlight 2015, pp. 1334-40). Thus their ability to vindicate their statutory rights may be reduced.

Moreover, the union will lose the ability to influence interpretation of the contract by controlling which cases go to arbitration. Individual employees may argue for contractual interpretations that win individual cases, but ultimately harm the employees as a group. Hard cases that make bad law may find their way to arbitration, damaging employee contractual rights. These cases may complicate 
future labor negotiations by forcing unions to expend negotiating capital to recover contractual rights that would not otherwise have been lost, diminishing their ability to gain in other areas.

Another interpretation of law that may be revisited by the NLRB, similar state agencies, or even legislative bodies, is minority unions. Based on extensive historical research, Professor Charles Morris has persuasively argued that the NLRA requires employers to bargain with minority unions before majority representation is established (Morris 2004). The NLRB has thus far rejected labor's efforts to obtain a reinterpretation in accord with this analysis (Dick's Sporting Goods 2006; Order, In Re: Petition for Rulemaking Regarding Members-Only Minority-Union Collective Bargaining 2011). According to this interpretation, nonmajority representation precedes majority representation but once majority representation occurs, exclusive representation applies. Changes in the law relating to the right to charge for union representation that cast doubt on the survival of the existing system might provide greater incentive for the NLRB to reconsider the interpretation of the law regarding minority unions (Fisk \& Sachs 2014, pp. 866-74). Minority bargaining would require, indeed allow, the union to represent only its members. This practice was common in the early years after the passage of the NLRA (Morris 2004, pp. 8285). Employers would be required to bargain more frequently and indeed, might have to bargain with multiple unions each representing their own membership. Each union would prioritize in negotiations the interests of its members. Standardization of employment terms could be more difficult. The employer might apply union-negotiated terms to all employees for administrative purposes, and 
depending on the application of the law with regard to discrimination might have to, but at the very least, the union could advocate only for its members for contract enforcement purposes. Based on the European experience, multiple representation makes both bargaining and contract administration more complex (Sheldon 2014, p. 699).

Ultimately, the entire system of exclusive representation may be threatened by changes in the law. The stability that results from exclusive representation is one of the primary benefits of the system for the employer and for the union that has representation rights (although not for competing unions). This stability has been the foundation of a number of decisions interpreting the statute including the NLRB's recent decision not to exercise jurisdiction over college football players (Northwestern University, 2015). Other notable decisions relying on the stability rationale are cases allowing for a time period for negotiations when no employee, employer or other union may challenge the representation status of the union (DauSchmidt 2014, p. 521-22). A new system may not value stability so highly.

Thus, the elimination of fair share will affect both the actors in the labor relations system and the structure of the system itself. The effects on the two are intertwined, for the actors, employers, employees and unions, affect the system, while the system also shapes the roles of the actors. Favorable law may contribute to union strength but it is not a prerequisite to it (Hodges, 2011, pp. 905-910).

\section{Conclusion}

As noted above, it is unlikely that conflict in the workplace will disappear. We may see a period where employees with limited outlets for voice in the 
workplace are relatively silent. Nevertheless there will be resistance, as evidence indicates that even slaves found small ways to protest against their masters. And if working conditions are difficult ultimately silence will end, as it did in the $19^{\text {th }}$ and $20^{\text {th }}$ centuries. The strategies that labor has begun to employ may expand.

Grassroots worker advocacy organizations may expand their efforts, utilizing tactics such as short strikes or protests, product boycotts and legal actions on behalf of employees, as well as political activity. Craft-like unions that seek to control the supply of workers in a given craft, similar to construction unions or entertainment unions, may increase in number. Where the craft is highly skilled and the workers disciplined, such unions can be powerful forces. Political unions may grow, choosing to focus on broader political actions rather than more employer-focused "business unionism," the model that American unions adopted years ago. A surge of spontaneous protests is possible, where unrepresented workers, uncontrolled by union discipline, erupt when conditions become sufficiently severe that the desire to retain employment is trumped by frustration and outrage. When strikes or demonstrations are spontaneous responses to long-simmering grievances, rather than planned tactics to advance union positions in negotiations, violence is more likely. Unions that have evolved into institutions with resources are less likely to engage in tactics ruled unlawful, such as sitdown strikes or work stoppages that cause serious damages to employer products and facilities (Dau-Schmidt $2014 \mathrm{pp}$. 207-18). Even if prohibitions on damaging strike tactics survive the demise of exclusive representation, and they probably would, organizations with few resources or employees pushed to their limit without organizational resources and 
advice may be less likely to refrain from such conduct. And if violent or damaging demonstrations become more common, the response will be either further repression or new law to channel the conflict into more acceptable formats. And America will be back to the conditions that led to the origins of the existing law in the 1930 s.

Conflict, combined with activist union pressure, may lead to legal changes. In the long run, we may see a renewal of the principles of existing law, as is or with minor modifications, or a different system that eschews exclusive representation altogether. Many of the European systems, which do not rely on exclusive representation or union security, have highly centralized determination of terms and conditions of employment for workers in common industries, either through multi-employer bargaining or through incorporation of agreements into the law (Sheldon 2014, pp. 688-89, 694, 698-99). Professor Dimick has argued that the European system increases employer flexibility and improves productivity (Dimick, 2014, pp. 691-99). He submits that it would require limited legal change but a substantial change in union strategy (Dimick 2014, pp. 716-23). Such a system is not effective, however, without politically powerful unions. Dimick proposes that this could be accomplished by organizing multiple employers in an industry on a members-only basis (Dimick 2014, pp. 719-21). Some countries, such as Germany and the Scandinavian countries, have thriving economies using this model. Other countries with similar models have high unemployment, and, at least currently, troubled economies, not exclusively and perhaps not predominantly attributable to the labor relations system. It seems unlikely that the U.S. would adopt such a 
system without a significant change in the current political climate and culture, but substantial disruption and conflict might bring surprising results.

Nothing is certain when longstanding systems are dismantled. We are in the midst of an economic and workplace transformation not unlike the industrial revolution. Change is inevitable. New conditions may lead to new systems more suited to current needs. There is little doubt, however, that any change will be uncomfortable, if not painful, for those accustomed to the existing order. There is also little doubt that workplace conflict will not abate completely and if surpressed, will rise again. Perhaps this has been an exercise only for the imagination. It is possible that the existing labor relations system will survive the current attacks. Labor may limp along in a weakened state or be strengthened by the challenges. But it behooves us as scholars and practitioners to contemplate the past and consider the future of the labor relations system to preserve what is valuable and change what is not.

\section{Compliance with Ethical Standards}

The author declares that she has no conflicts of interest. This article does not contain any studies with human participants or animals performed by either of the authors. There were no individual participants in this study and, thus, informed consent does not apply to this study.

\section{References}

115 Illinois Compiled Statutes 5/10(c).

14 Penn Plaza v. Pyett, (2009) 556 U.S. 247, 265-66, 274.

5 Illinois Compiled Statutes 315/8. 
Abood v. Detroit Board of Education (1977), 431 U.S. 209, 221-22, 235-36.

Bauer, S. (2015). Seeking '16 Spark, Walker Proposes Vast Union Restrictions. Yahoo, (September 14). Online at: http://news.yahoo.com/seeking-16-sparkwalker-proposes-122257371.html Accessed October 30, 2015.

Bernstein, I. (1970). The Turbulent Years. Boston, Massachusetts: Houghton Mifflin.

Bok, D. (1971). Reflections on the Distinctive Character of American Labor Laws. Harvard Law Review, 84, 1394-1426.

Bureau of Labor Statistics (2015), Union Affiliation of Employed Wage and Salary Workers by State. Bureau of Labor Statistics, (January 23). Online at:

http://www.bls.gov/news.release/union2.t05.htm Accessed October 30, 2015.

Cadelago, C. (2015). California Union Fees Case Spurring Late Session Talks at Capitol. Sacramento Bee, (September 4). Online at:

http://www.sacbee.com/news/politics-government/capitol-

alert/article34092858.html Accessed October 30, 2015.

Communications Workers of America (CWA) v. Beck (1988), 487 U.S. 735, 762-63.

Cone v. Nevada Serv. Employees Union/SEIU Local 1107 (2000) 116 Nev. 473, 998 P.2d 1178.

Dau-Schmidt, K., et al. (2014). Labor Law in the Contemporary Workplace (2d ed.). St. Paul: West Academic Publishing.

Devinatz, V. (2015). Why Politics Should Not be Liberated from Collective Bargaining: Problems with the Unbundled Union Regime. Labor Law Journal 66, 99110.

Dick's Sporting Goods (2006), 2006 WL 2992401.

Dimick, M. (2014). Productive Unionism. UC Irvine Law Review, 4, 679-724.

Duff, M. (2011). Of Courage, Tumult, and the Smash Mouth Truth: A Union Side Apologia. Employee Rights \& Employment Policy Journal, 15, 521-44.

Dziembowska, M. (2010). NDLON and the History of Day Labor Organizing in Los Angeles. In Milkman, R. (Ed.), Working for Justice, The L.A. Model of Organizing and Advocacy, 141-53. Ithaca, New York: Cornell University Press.

Fine, J. (2006). Worker Centers: Organizing Communities at the Edge of the Dream. Ithaca, New York: Cornell University Press. 
Fisk, C. \& Chemerinsky, E. (2013). Political Speech and Association Rights After Knox v. SEIU, Local 1000. Cornell Law Review, 98, 1023-92.

Fisk, C. \& Poueymirou, M. (2015). Harris v. Quinn and the Contradictions of Compelled Speech, Loyola Los Angeles Law Review, 48, 413-65

Fisk, C. \& Sachs, B. (2014). Restoring Equity in Right-to-Work Law. UC Irvine Law Review, 4, 857-880.

Friedrichs v. California Teachers Association (2016),136 S.Ct. 1083.

Friedrichs v. California Teachers Association (2015) 135 S. Ct. 2933.

Garea, S. \& Stern, S. (2010). From Legal Advocacy to Organizing. In Milkman, R., (Ed.), Working for Justice, The L.A. Model of Organizing and Advocacy, 125-40. Ithaca, New York: Cornell University Press.

Getman, J. (2010). Restoring the Power of Unions. New Haven, Connecticut: Yale University Press.

Harris v. Quinn (2014) 124 S.Ct. 2618.

Heynen, N. (2015). Interactive Map: States with Right to Work Laws. Madison, (March 9). Online at: http://host.madison.com/news/local/govt-andpolitics/interactive-map-states-with-right-to-work-laws/html_6de12bf1-8ae85cb9-901f-b9eec38df1e5.html Accessed October 30, 2015.

Hodges, A. \& Warwick, W. (2012). The Sheathed Sword: Public-Sector Union Efficacy in Non-Bargaining States. ABA Journal of Labor \& Employment Law, 27, 27591.

Hodges, A. (2012). Maintaining Union Resources in an Era of Public-Sector Bargaining Retrenchment. Employee Rights and Employment Policy Journal, 16, 599628.

Hodges, A. (2011). Avoiding Legal Seduction: Reinvigorating the Labor Movement to Balance Corporate Power. Marquette Law Review, 94, 889-916.

Hodges, A. (2010). Fallout From 14 Penn v. Pyett: Fractured Arbitration Systems in the Unionized Workplace. Journal of Dispute Resolution, 2010, 19-56.

Hodges, A. (2009). Lessons from the Laboratory: The Polar Opposites on the Public Sector Labor Law Spectrum. Cornell Journal of Law \& Public Policy, 18, 735-73. 
Hurd, R. W. (1989). Organizing Clerical Workers. In P. Wilson (Ed.), Meeting the Challenges of Change: Unions and the White Collar Workforce, 5-11, Washington D.C.: AFL-CIO.

Knox v. SEIU Local 1000 (2012), 132 S. Ct. 2277.

Lazonick, W. (2015). Labor in the $21^{\text {st }}$ Century: The Top $0.1 \%$ and the Disappearing Middle Class. In Weller, C. (Ed.), Inequality, Uncertainty and Opportunity: The Varied and Growing Role of Finance in Labor Relations, 143-95. Champaign, Illinois: Labor and Employment Relations Association.

Making Change at WalMart (2015), Online at: http://makingchangeatwalmart.org/about/ Accessed October 31, 2015.

Malin, M., et al. (2011). Public Sector Employment, 2d ed., Thompson West.

Milkman, R., et al. (2010). Working for Justice, The L.A. Model of Organizing and Advocacy. Ithaca, New York: Cornell University Press.

Mishel, L. (2012). Unions, inequality, and faltering middle-class wages. Economic Policy Institute, (August 29). Online at: http://www.epi.org/publication/ib342unions-inequality-faltering-middle-class/ Accessed October 31, 2015.

Morris, C. (2004). The Blue Eagle at Work. Ithaca, New York: Cornell University Press.

Narro, V. (2008). Finding the Synergy Between Law and Organizing: Experiences from the Streets of Los Angeles. Fordham Urban Law Journal, 38. 339-72.

National Labor Relations Act § 14(b), 29 U.S.C. § 164(b).

Northwestern University (2015) 362 NLRB No. 167.

Notice and Invitation to File Briefs (2015), United Steel \& Service Workers International Union, Case No. 12-CB-109654.

Olson, M. (1971). The Logic of Collective Action: Public Goods and the Theory of Groups. Cambridge, Massachusetts: Harvard University Press.

Order, In Re: Petition for Rulemaking Regarding Members-Only Minority-Union Collective Bargaining (2011).

Oswalt, M. (2016). Improvisational Unionism. California Law Review, 104, 1-87 (forthcoming), available at http://papers.ssrn.com/sol3/papers.cfm?abstract_id=2577420\&download=yes. 
Oswalt, M. (2007). The Grand Bargain: Revitalizing Labor Through NLRA Reform and Radical Workplace Relations. Duke Law Journal, 57, 691-725.

Putnam, R. (2000). Bowling Alone. New York, New York: Simon \& Schuster.

Rosenfeld, D. (2006). Worker Centers; Emerging Labor Organizations - Until They Confront the National Labor Relations Act. Berkeley Journal Employment \& Labor Law, 27, 469-514.

Sachs, B. (2013). The Unbundled Union: Politics Without Collective Bargaining. Yale Law Journal, 123, 148-207.

Schiavone, M., (2008). Unions In Crisis? The Future of Organized Labor in America. Westport, Connecticut: Praeger.

Sheldon, P., et al., (2014). Collective Bargaining: Globalizing Economies and Diverse Outcomes. In Blanpain, R. (Ed.), Comparative Labour Law and Industrial Relations in Industrialized Market Economies, 681-730. The Netherlands: Kluwer Law International.

Sternlight, J. (2015). Disarming Employees How American Employers Are Using Mandatory Arbitration to Deprive Workers of Legal Protection. Brooklyn Law Review, 80, 1309-56.

United Steel \& Service Workers International Union, (2014) Case No. 12-CB109654, Administrative Law Judge Decision.

Vegelahn v. Guntner (1896), 167 Mass. 92, 108, 44 N.E. 1077, 1081, Holmes, J. dissenting.

Ann C. Hodges is Professor of Law at the University of Richmond. Her teaching and research focuses on labor and employment law. Prior to joining the University she practiced labor law with the Chicago firm of Katz, Friedman and served as a Field Examiner with the National Labor Relations Board. 